\title{
Adeno Squamous Palpebral Carcinome with Orbitary Extension: Case Report
}

\author{
Imad L*, Naya K, Hasnaoui I, Abdellah E and \\ Berraho A \\ Department of Ophthalmology B, Ibn Sina Hospital, \\ University Mohamed V, Rabat, Morocco \\ *Corresponding author: Lidya Imad, Department \\ of Ophthalmology B, Ibn Sina Hospital, University \\ Mohamed V, Rabat, Morocco
}

Received: April 07, 2021; Accepted: May 01, 2021; Published: May 08, 2021

\begin{abstract}
Adeno-Squamous Carcinoma (ASC) is a neoplastic variety characterized histologically by the presence of 2 distinct carcinomatous contingents, adenomatous and squamous.

This tumor form is extremely rare, and even more so in its palpebral localization.

In the light of this observation, we will expose the anatomo-clinical and evolutionary peculiarities of this uncommon variant.

Keywords: Adeno-squamous Carcinoma; Eyelid; Orbitary extension; Exenteration
\end{abstract}

\section{Case Presentation}

This 27-year-old presents with a left internal canthal swelling, increasing in volume over the last 5 months.

The ophthalmologic examination finds a left internal canthal ulcer-burgeoning process extending over the internal $1 / 3$ of the lower eyelid with inflammatory signs; the rest of the examination is normal [1-3].

Tumor biopsy with anatomo-pathological study confirms the diagnosis of well-differentiated adeno-squamous carcinoma [4].

Orbital-facial CT scan reveals a left internal canthal tissue process extending into the nasolacrimal duct.

The patient benefited from Exenteration with osteotomies on the nasolacrimal duct and nasal fossae [5,6].

Post-operative follow-up (clinical and radiological) showed no residual process, local recurrence or distant metastasis.

\section{Discussion}

The palpebral localization of ASC is Extremely Inhabitual and Disorderant with the hypotheses that explain that its histogenesis is of Glandular origin, since this type of histology is frequently found in organs where adenocarcinomas predominate (stomach, uterus) [7-9].

Our case assumes the surface epithelium as histo-genetic origin, and joins the recent publications reporting cases of ASC in the oral, nasal, laryngeal and esophageal mucosa [10].

Histological diagnosis is not easy, as several carcinomas have adenoid features (e.g. mucoepidermal carcinoma) which make it difficult to distinguish ASC, and this highly malignant tumor may be missed $[11,12]$.

Indeed, our case reflects an extreme loco regional aggressiveness, and even if the surgical exeresis was successful (histologically intact surgical margins), the prognosis remains unfavorable and unpredictable.

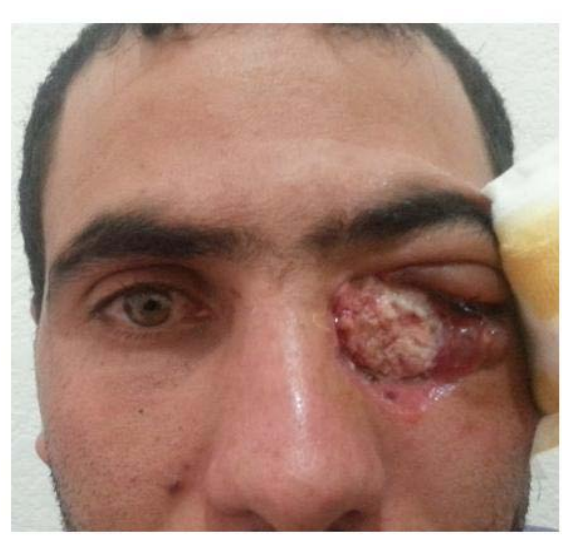

Figure 1: Superinfected ulcerous budding tumor of the left internal cantus.
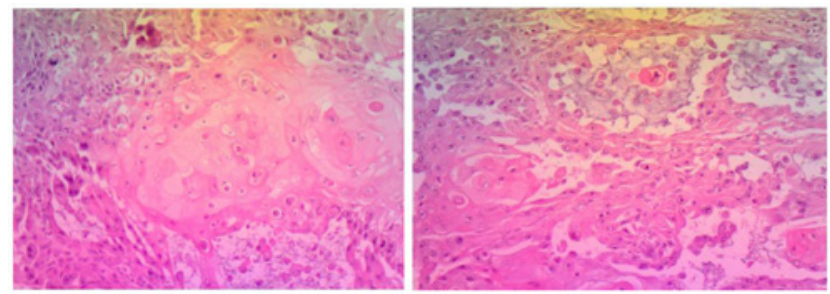

Figure 2-3: Tumor proliferation with cells in clumps with squamous differentiation, and others arranged around glandular slits.

\section{Conclusion}

Adeno-squamous carcinoma is an extremely rare and particularly aggressive histological variety of palpebral tumors, described as high-grade malignancy. It can only be diagnosed by pathological examination.

Awareness of this rare diagnosis allows the surgeon to adapt his or her surgical margins and to carry out armed post-operative surveillance. 

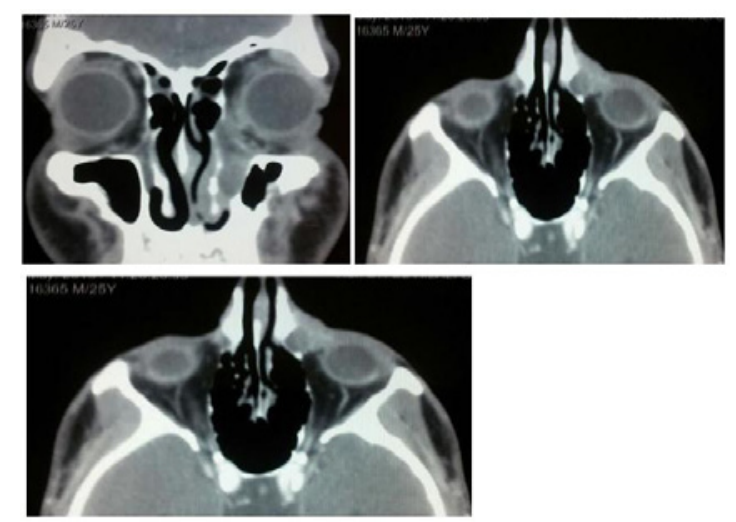

Figure 4: Orofacial CT scan: left medial canthal tissue process extending into the nasolacrimal duct.

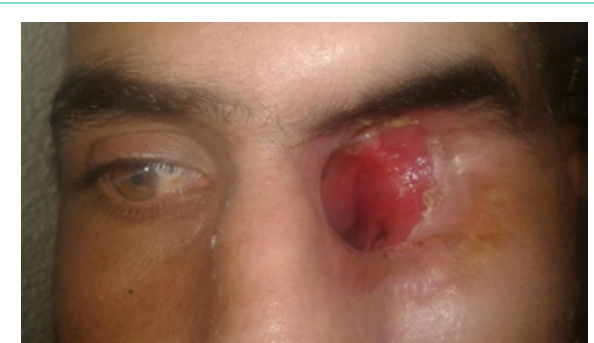

Figure 5: Exenteration with osteotomies on the nasolacrimal duct and nasal cavity.

\section{References}

1. JP Adenis, A Sabatier, P-Y Robert. Les tumeurs des paupières des personnes âgées. Journal Français d'Ophtalmologie. 2006; 29: 687-693.
2. Adenis JP, Smolik I, Catanzo G. Tumeurs des paupières aspects cliniques et thérapeutiques. In: Chirurgie palpébrale. Doin, Paris. 1991: 97-130.

3. Adenis JP, Smolik I, Lasudry J. Tumeurs palpébrales Aspects cliniques, anatomopathologiques et thérapeutiques. In: JP Adenis, S éd Morax (Ed.) Pathologie orbitopalpébrale Paris: Masson. 1998: 311-338.

4. JP Adenis, S Morax. Chirurgie palpébrale EMC Doin Editeurs, Paris. 1991: 99-106.

5. Barraco P, Hamedani M, Ameline-Audelan V, Morax S. Surgical treatment of eyelid tumors. Journal Français d'Ophtalmologie. 2003; 26: 92-102.

6. Basset-Séguin N. Cancérogénèse cutanée. In: Saurat JH, Grosshans E, Laugier P, Lachapelle JM. Dermatologie et maladies sexuellement transmissibles. Paris: Masson, 1999: 564-565.

7. Beyer-Machule CK, Riedel KG. Basal cell carcinoma. In: DM Albert, FA eds Jakobiec (Ed.) Principles and practice of ophthalmology. Philadelphia: WB Saunders. 1994: 1724-1733.

8. Broadland DG, Zitelli JA. Surgical margins for excision of primary cutaneaous squamous cell carcinoma. J Acad Dermatol. 1992; 27: 241-248.

9. Cockerell CJ. Histopathology of incipient intraepidermal squamous cell carcinoma. J Am Acad Dermatol. 2000; 42: 11-17.

10. Ducasse A, Desphieux JL, Pluot M, Segal A. Les tumeurs malignes de paupière. Aspects cliniques, histopathologiques et prise en charge chirurgicale. Ophtalmologie. 1995; 9: 362-366.

11. Hornblass A. Tumors of the ocular adnexa and orbit. CV Mosby Company st. Louis. 1979: 336.

12. Jakobiec FA. Sebaceous tumors of the ocular adnexa. In: Albert DM, Jakobiec FA, ed. Principles and practice of ophthalmology. Philadelphia: Saunders, 1994:1745-1770. 